\title{
Palaeolimnology of the Santa Clara Abajo Formation, Triassic of the Cuyana Basin Argentina, inferred from fish taphonomy
}

\author{
CECILIA A. BENAVENTE @ , P. GUILLERMINA GIORDANO AND ADRIANA C. MANCUSO
}

\section{LETHAIA}

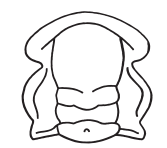

Benavente, C. A., Giordano, P. G., \& Mancusoa, A. C.2021: Palaeolimnology of the Santa Clara Abajo Formation, Triassic of the Cuyana Basin Argentina, inferred from fish taphonomy. Lethaia, Vol. 54, pp. 40-54.

The Santa Clara Abajo Formation in the north of Mendoza Province, Argentina, is part of the Triassic Cuyana rift Basin infill and consists of fluvial, deltaic and lacustrine units. The combination of progradational to aggradational stacking pattern plus the identification of a fluctuating profundal facies association suggests the Santa Clara Abajo palaeolake was a balanced-fill lake system. Lake-centre sediments (finely laminated mudrock facies) preserve pseudobeaconiid actinopterygian fish represented primarily by bones and scales, generally undeformed and concordant with bedding planes. We propose that variation of articulation degree of these fish combined with sediment features provides insights into palaeolimnological changes in this single lake system over time, primarily water temperature. The fish fossils are sorted into three taphonomic modes: Mode A, isolated and dispersed scales; Mode B, associated but dispersed scales, loosely to well sorted, and low to moderate density; and Mode C, scale patches and articulated fishes. We conclude these modes represent, respectively, warm, fluctuating warm-cold and cold water conditions. Stratigraphical analysis of the taphonomic modes for the balanced-fill lake model revealed an up-section pattern of fluctuating water temperatures (cold and warm), to a stable-cold pattern, to a stable-warm pattern and to fluctuating thermal conditions (cold and warm) again. This pattern is linked to lake-level fluctuations resulting in lacustrine intervals that reflect hydrological closure to opening to closure again. $\square$ Actinopterygii, lake-basin-type model, Mendoza, Santa Clara sub-basin, Triassic.

Cecilia A. Benavente凶[cebenavente@gmail.com], and Adriana C. Mancuso[amancu@ mendoza-conicet.gov.ar], IANIGLA, CCT-CONICET, Adrián Ruiz Leal s/n, Parque Gral. San MartínCC330, CP5500, Mendoza, Argentina; P. Guillermina Giordano [guillerminagiordano@gmail.com], Área de Zoología, Facultad de Química Bioquímica y Farmacia, Universidad Nacional de San Luis, Ejército de Los Andes 950 CP: 5700, San Luis, Argentina; manuscript received on 10/05/2019; manuscript accepted on 7/02/2020.

Lacustrine systems are dynamic and respond to a variety of influences, including environmental fluctuations, lithology of the watershed, drainage networks, basin configuration and other factors (GierlowskiKordesch \& Kelts 1994; 2000; Bohacs et al. 2000). Through these vectors, the tectonic and climatic changes shape lake basins over time (GierlowskiKordesch \& Kelts 2000). The stratigraphical evolution within a rift basin results from a balance between sediment supply, water supply and accommodation. This produces lake basins that generally fall into three basin categories described as underfilled, balanced-fill and overfilled (Bohacs et al. 2000). These lake types are represented by three main facies associations, respectively: evaporative, fluctuating profundal and fluvial-lacustrine (Bohacs et al. 2000).

Lake deposits also show rich and diverse assemblages of biota that characterize the ecological aspects of the local and regional area since they encompass both autochthonous and allochthonous organism remains (Behrensmeyer \& Hook 1992; Scholz et al. 2003). This results in informative facies regarding palaeoecology and depositional histories of continental basins and results in lakes providing significant archives of the palaeoenvironmental and palaeontological record (e.g. McCunne 1987; GierlowskiKordesch \& Kelts 1994; Talbot \& Allen 1996).

There are many ways of approaching the multiproxy record in lacustrine rocks depending on the questions that are addressed. Taphonomy is an integrative discipline and a valuable instrument in the reconstruction of palaeoenvironments (Behrensmeyer \& Kidwell 1985; Behrensmeyer \& Hook 1992). The interpretation of processes, as well as, their agents, that affected an organism between death and fossilization, in a sedimentary framework, allows the building of a taphonomic history (Behrensmeyer \& Hook 1992; Behrensmeyer \& Kidwell 1985). This history, along with a sedimentological analysis of the locality, allows the reconstruction of the palaeoenvironment (Wilson 1988). 
The taphonomic analysis of lacustrine fish remains establishes preservational modes that illuminate species composition, size of specimens, disarticulation of skeletons and other relevant data (McCune 1987; Wilson 1988; Elder \& Smith 1988; Mancuso 2012). Those data allow inferring palaeoenvironmental characteristics such as hydrochemistry, temperature and oxygenation (McCune 1990; Ferber \& Wells 1995; Barton \& Wilson 2005; Whiteside et al. 2011). This type of palaeoenvironmental reconstruction has been successfully demonstrated in previous work (Wilson 1996; Wilson \& Barton 1996; Chen 2000; Mancuso 2003; Fürsich et al. 2007; Stigall et al. 2008; Mancuso 2012).

The Santa Clara Abajo Formation belongs to the El Peñasco Group (Spalletti \& Zavattieri 2009) and represents part of the infilling in the northern area of the Triassic Cuyana rift Basin. The deposits of the succession represent a fluvial-deltaic-lacustrine system. Little is known about this succession, and previous work has focused exclusively on the systematics and taxonomy of the actinopterygian fishes, identified as Pseudobeaconiidae based on the complete specimens known until that time (López-Arbarello et al. 2010).

The aims of this study are (1) to sedimentologically characterize the palaeoenvironments and depositional setting represented by the Santa Clara Abajo Formation; (2) to provide taphonomic data of new pseudobeaconid fish specimens collected under detailed stratigraphical control from the unit; and (3) to integrate taphonomic and sedimentological data and provide a palaeolimnological proxy that allows assessment of conditions in the Triassic fluvial-lacustrine system.

\section{Geological setting}

The Santa Clara sub-basin is part of the Cuyana rift Basin, included in the northern area of the rift with the active margin in the east (Fig. 1). All continental Triassic units that crop out in the area (Stappenbeck 1910; Stipanicic 1947; Groeber \& Stipanicic 1953; Spalletti 2001) are part of the El Peñasco Group (Cortés et al. 2003; Spalletti \& Zavattieri 2009), composed of five sedimentary units, named from base to top: Cielo, Mollar, Montaña, Santa Clara Abajo and Santa Clara Arriba formations (Zavattieri 2002; Spalletti \& Zavattieri 2009). Unfortunately, so far, this Group lacks chronostratigraphical resolution.

The Cielo Formation presents coarse-grained sandstones forming thick strata and massive conglomerates with a sandstone matrix (Harrington 1971). The Mollar Formation is formed by finegrained, stratified to massive sandstones alternating with carbon-rich black mudstones (Harrington 1971). This unit has been interpreted as a lacustrine system with small-scale cycles representing lake expansion and contraction (Spalletti \& Zavattieri 2009). The Montaña Formation presents coarsegrained stratified sandstones interbedded with finely stratified siltstones (Harrington 1971). This unit has been interpreted as a fluvial system with wood remains found in the fluvial plain (Artabe et al. 2003). The Santa Clara Abajo Formation presents siltstones, fossiliferous mudstones, sandstones and subordinated conglomerates (Harrington 1971). Fish remains have been recovered from mudstone units (López-Albarello \& Zavattieri 2008). The stratigraphical column for this unit at its type locality (Santa Clara Creek; Fig. 1) shows the interbedding of a single lacustrine subenvironment with marginal deposits and fluvial-deltaic influence (Fig. 2). The Santa Clara Arriba Formation is mainly represented by thin clayey to tuffaceous fine-grained sandstones that alternate with laminated mudstones and siltstones (Harrington 1971). The palaeoenvironment of this unit has been interpreted as a low gradient deltaiclacustrine system (Benavente et al. 2018).

\section{Material and methods}

During fieldwork, we measured high-resolution sedimentary logs, facies and associations of facies. Colour descriptions in the field follow the Rock Colour Chart of the Geological Society of America.

Palaeontological sampling consisted of systematic field collection with detailed stratigraphical control, considering the precise stratigraphical level and orientation of fish specimens with respect to north in the sedimentary layers. Fish samples were analysed and mechanically prepared at the Universidad Nacional de San Luis (UNSL) under a binocular microscope (Leica M80).

\section{Fish material}

The studied material consists of 160 samples of scales and body remains of mainly adult fish identified as Pseudobeaconiidae, a family of Triassic Actinopterygii restricted to the Southern Hemisphere (LópezArbarello \& Zavattieri 2008). Four species of Pseudobeaconia (P. celestae, P. bracaccinii, P. elegans and $P$. cuyana) and only one species of Mendocinichthys (M. brevis) are known for the family Pseudobeaconiidae (López-Arbarello et al. 2010). Three of these five species come from the Santa Clara Abajo Formation and were described by Bordas (1944). The assemblage of pseudobeaconiids studied here is probably 


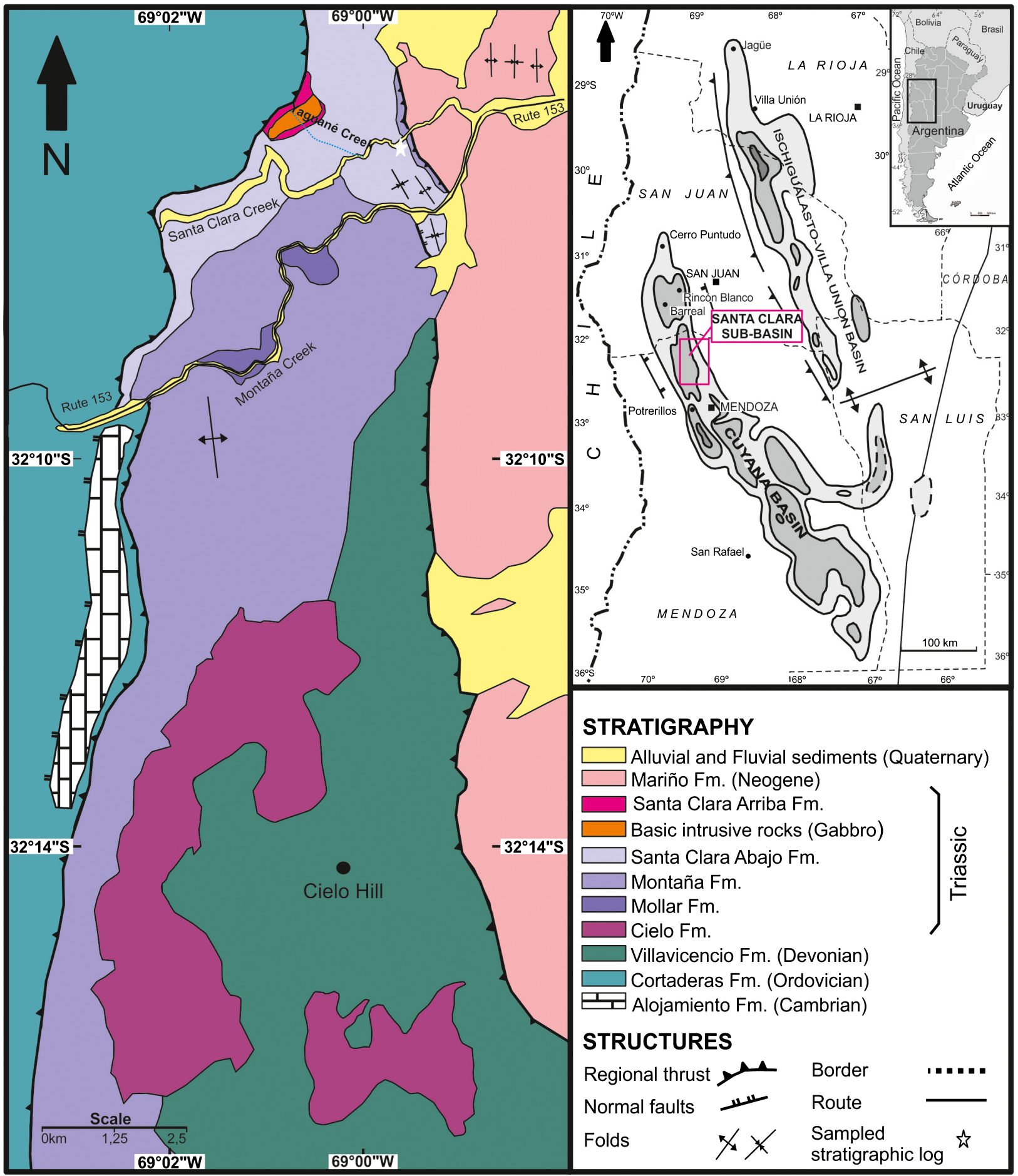

Fig. 1. Location map, geological map and stratigraphy of the Santa Clara sub-basin, in the north region of the Cuyana rift Basin, Argentina. Modified from Benavente et al. (2018). [Colour figure can be viewed at wileyonlinelibrary.com

monospecific, but a detailed taxonomic revision is necessary in the future to confirm our preliminary identifications. Fish remains have been collected in a single locality, in the Santa Clara Creek (Fig. 1), and are deposited in the Palaeovertebrate Collection of the Instituto Argentino de Nivología, Glaciología y Ciencias Ambientales (IANIGLA) (IANIGLA-PV 881 to 892), Mendoza city, Argentina. 


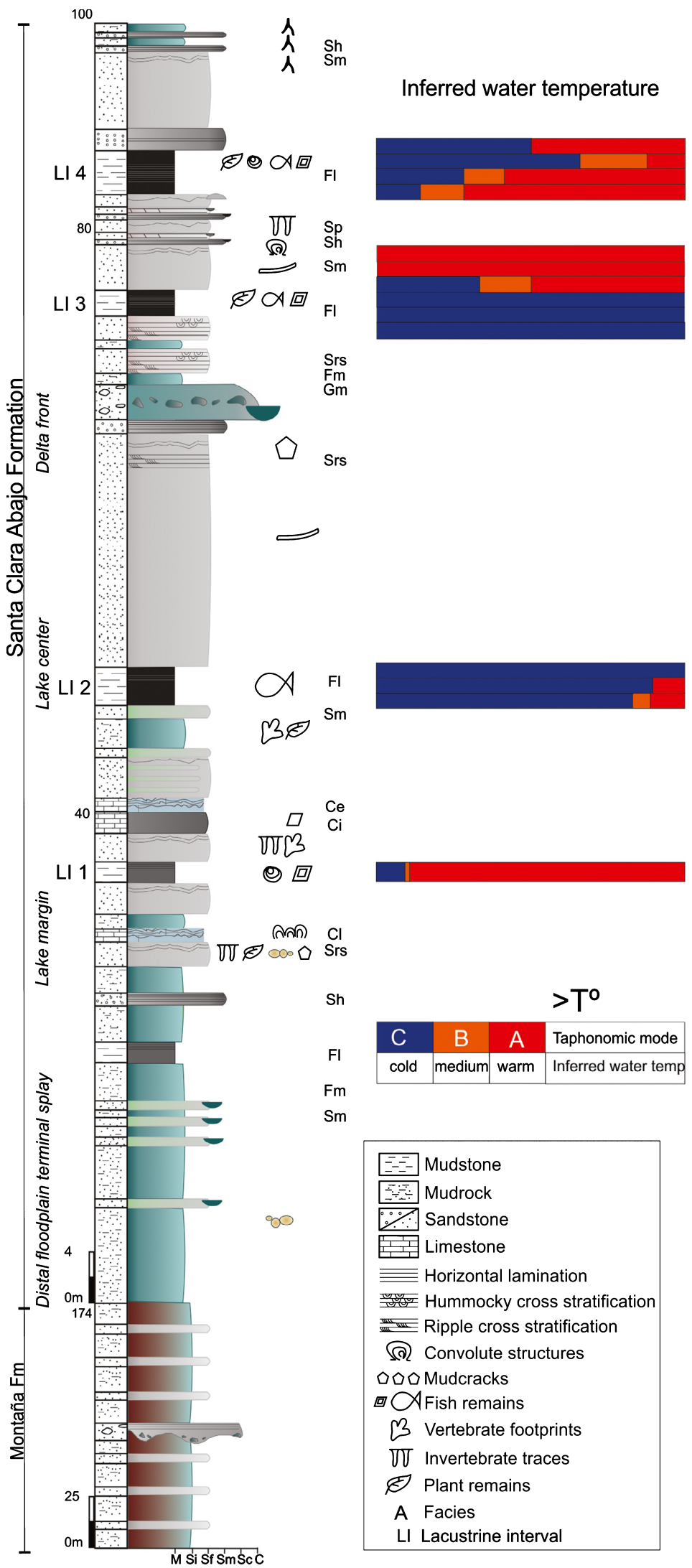

Fig. 2. Stratigraphical log of the Santa Clara Abajo Formation in the Santa Clara sub-basin, Cuyana rift Basin, Argentina. (Location of log is shown in Fig. 1). Inferred water temperatures for horizons are based on taphonomic modes (degree of articulation/disarticulation). [Colour figure can be viewed at wileyonlinelibrary.com 
Table 1. Taphonomic attributes and states defined for the fish remains of the Santa Clara Abajo Formation (Triassic) at the Santa Clara sub-basin, Central area of the Cuyana Basin, Mendoza, Argentina.

\begin{tabular}{ll}
\hline Taphonomic attribute & Possible states \\
\hline Remains & List of remains recorded \\
Taxa & List of taxa recorded \\
Mode of fossilization & Hard part, Cast \\
Degree of articulation & Isolate and dispersed \\
& Associated but dispersed \\
& Disarticulated but associated \\
& Articulated \\
Post-mortem modification & Absence \\
Compaction & Low \\
Abrasion & Moderate \\
Cracking & High \\
Breakage & \\
Oxidation & \\
Recrystallization & \\
Deformation & \\
Spatial Pattern & Without preferential orientation \\
Orientation & Preferential orientation \\
Cross-cutting & Concordant \\
Biofabric & Discordant \\
Packing & Dispersed \\
& Loosely packed \\
Sorting & Densely packed \\
& Poorly sorted \\
Density & Loosely sorted \\
& Well-sorted \\
& Low \\
& Moderate \\
\hline
\end{tabular}

\section{Data analysis}

In this study, we defined taphonomic modes of fish specimens based on the preservational quality and taphonomic attributes such as degree of articulation, biofabric (packing, sorting and density), post-mortem modifications (compaction, abrasion, cracking, breakage, oxidation, recrystallization) and spatial arrangement (orientation, cross-cutting) (Table 1). The degree of articulation was our primary consideration because it is an indicator of temperature conditions (Smith \& Elder 1985; Elder \& Smith 1988; Barton \& Wilson 2005; Mancuso 2012). The host sediment is finely laminated mudstone.

\section{Results}

\section{Sedimentology}

The Santa Clara Abajo Formation consists of a $500 \mathrm{~m}$ thickness of finely laminated mudrock and siltstone with interbedded fine- to medium-grained sandstone, limestone and scarce lenticular clast- supported conglomerate (Figs 2,3). The detail of the facies defined for the unit is in Table 2.

Facies association A. - This facies association is represented by facies Sm and Fm (Table 2; Figs 2, 3a) and is characterized by structure-less tabular siltstone $(\mathrm{Fm})$ of pale blue green colour (5BG 7/2) with rounded nodules of light brown (5 YR 6/4), interstratified with isolated tabular to laterally amalgamated massive medium-grained sandstones (Sm) with slightly irregular to erosive bases. These sandstones are of yellowish grey colour (5Y 7/2).

The Fm facies suggests suspension settle-out processes from waning tractive flows or simply overbank flow into lake flood basins from channel tributaries (Makaske 2001; Stoner \& Holbrook 2010). Sm indicates tractive flows in the overbank of the distributary system confined to sheet-like flows of the distal zone of the tributary fluvial system (Nichols \& Fisher 2007). These sandstones commonly lack sedimentary structures due to pedogenic processes (Nichols \& Fisher 2007).

Facies association B. - This association is formed by facies Sh, Srs, Fh, Cl and Fl (Table 2; Fig. 3B-D). Facies Fm of facies association A passes upwards to finely laminated dark grey (N4) mudstone (Fl) with plant and fish remains (Fig. 3B) and is interstratified with medium-grained, moderately sorted sandstone with horizontal stratification (Sh) which is light grey (N8) to medium grey (N5) in colour. These sandstones form tabular to lenticular bodies with plant remains. In this facies association, Fh is characterized by abundant plant remains, vertebrate footprints, vertical and horizontal tubes, mudcracks (Fig. 3C) and rain-drop marks. It also passes upwards to fineto very fine-grained, well-sorted symmetric ripple, cross-laminated sandstone (Srs) of greenish grey colour $(5 \mathrm{G} \mathrm{6/1)}$. These sandstones underlie laminated to massive tabular carbonate $(\mathrm{Cl})$ of yellowish grey colour (5Y 8/1) (Fig. 3D) with intraclasts and are interstratified with the finely laminated dark grey (N4) mudstone (Fl).

The Fh facies indicates suspension settle-out processes from waning tractive flows entering a body of water (Larsen \& Smith 1999). Mudcracks, in Fh, are interpreted as desiccation cracks, within the muddy siltstone layers, indicating short periods of exposure between sedimentation events (Smoot \& Lowenstein 1991). Vertebrate footprints in this facies indicate that lake margin waters were shallow. Rain-drop marks point to exposures and pauses in sediment + water supply. Plant remains are interpreted as fragments transported from vegetated highlands (Mancuso 2009). The vertical and horizontal tubes 

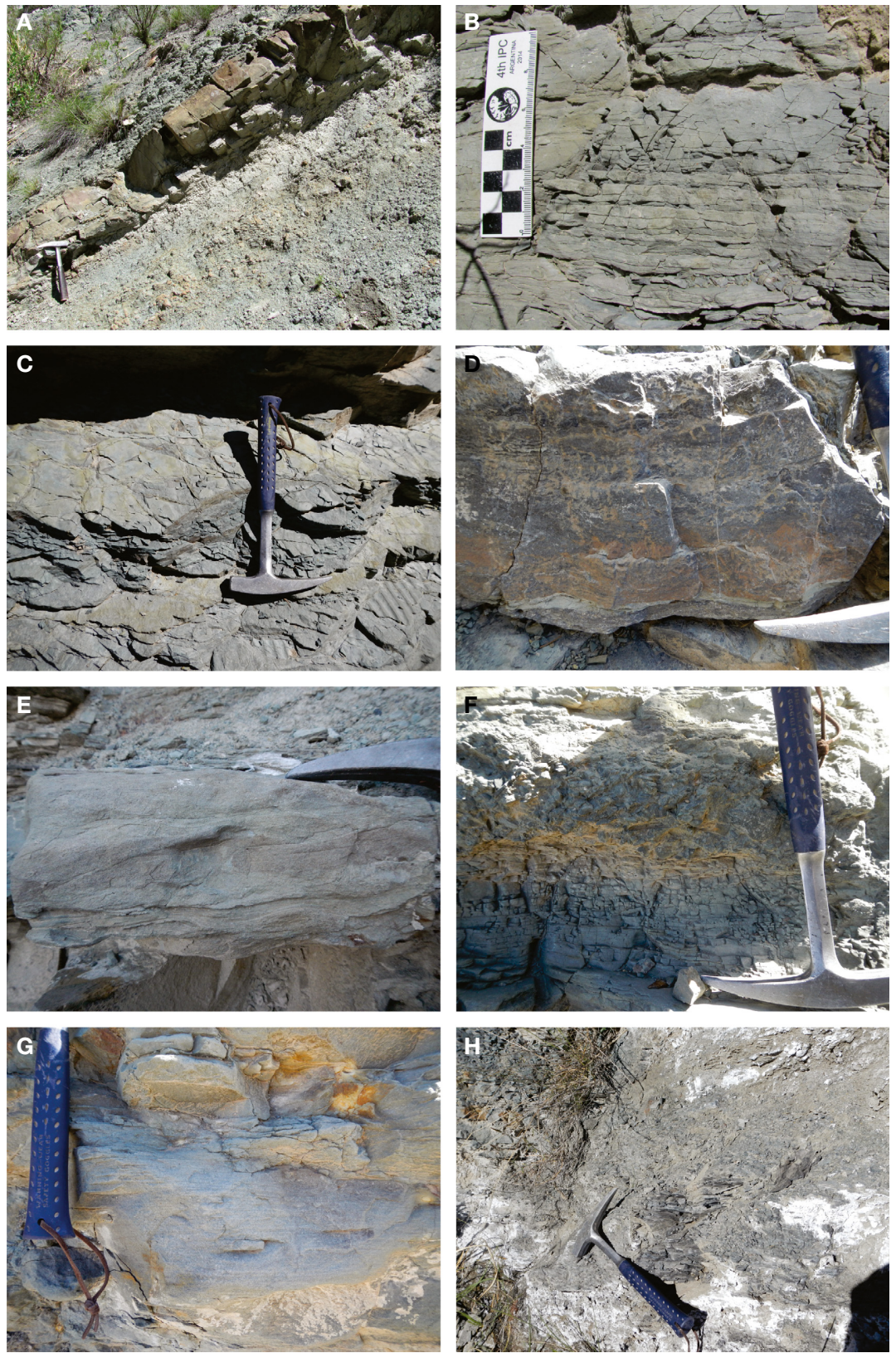

Fig. 3. Outcrop photographs of facies associations defined for the Santa Clara Abajo Formation, at the Santa Clara sub-basin, Cuyana rift Basin. A, detail of facies association A, showing isolated lenses of facies Sm interbedded with facies Fm. Hammer is $35 \mathrm{~cm}$. B-D, photographs of facies association B. B, detail of finely laminated Fh facies. Scale $=10 \mathrm{~cm}$. C, plan view of Fh facies showing polygonal mud cracks in muddy tops. Hammer is $35 \mathrm{~cm}$. D, detail of $\mathrm{Cl}$ facies showing discontinuous planar to domal lamination. Hammer is $35 \mathrm{~cm}$. EG, photographs of facies association C. E, detail of facies Srs with cut and fill structures. Hammer is $35 \mathrm{~cm}$. F, detail of Gm facies erosively overlying facies Fh. Hammer is $35 \mathrm{~cm}$. G, detail of faint $\mathrm{Fh}$ facies. Hammer is $35 \mathrm{~cm}$. H, outcrop photograph of facies $\mathrm{Fl}$ (facies association D). Hammer is $35 \mathrm{~cm}$. [Colour figure can be viewed at wileyonlinelibrary.com

are invertebrate burrows. Facies Srs shows wave reworking processes on sand within the lake margin (Nadon 1994). Planar and domal lamination of carbonate is interpreted as small-scale bioconstructions stabilized by microorganisms that favoured substrate biostabilization (Noffke et al. 2001). In general, this facies association represents sediment accumulation from tractive flows and suspension settle out, carbonate precipitation, and wave reworking processes at the margin of the lake, lateral to the main water + sediment supply to the system (Fisher et al. 2007).

Facies association C. - This facies association is represented by facies Sh, Srs, Gm, Sp and Fm (Table 2; Fig. $3 \mathrm{E}-\mathrm{G})$ and is characterized by well-sorted 


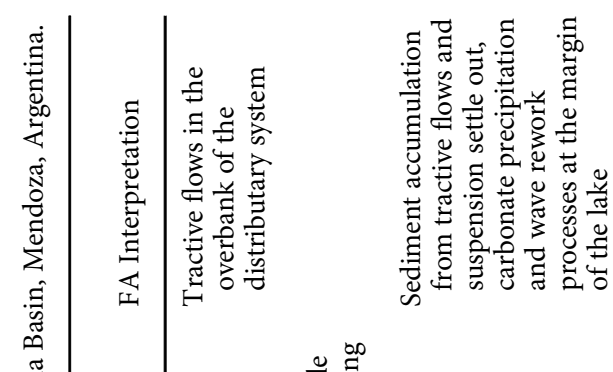

$\sum_{3}^{\infty}$
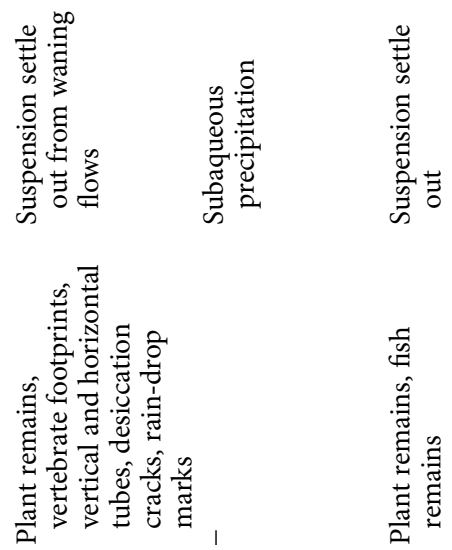

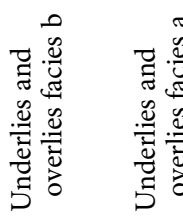
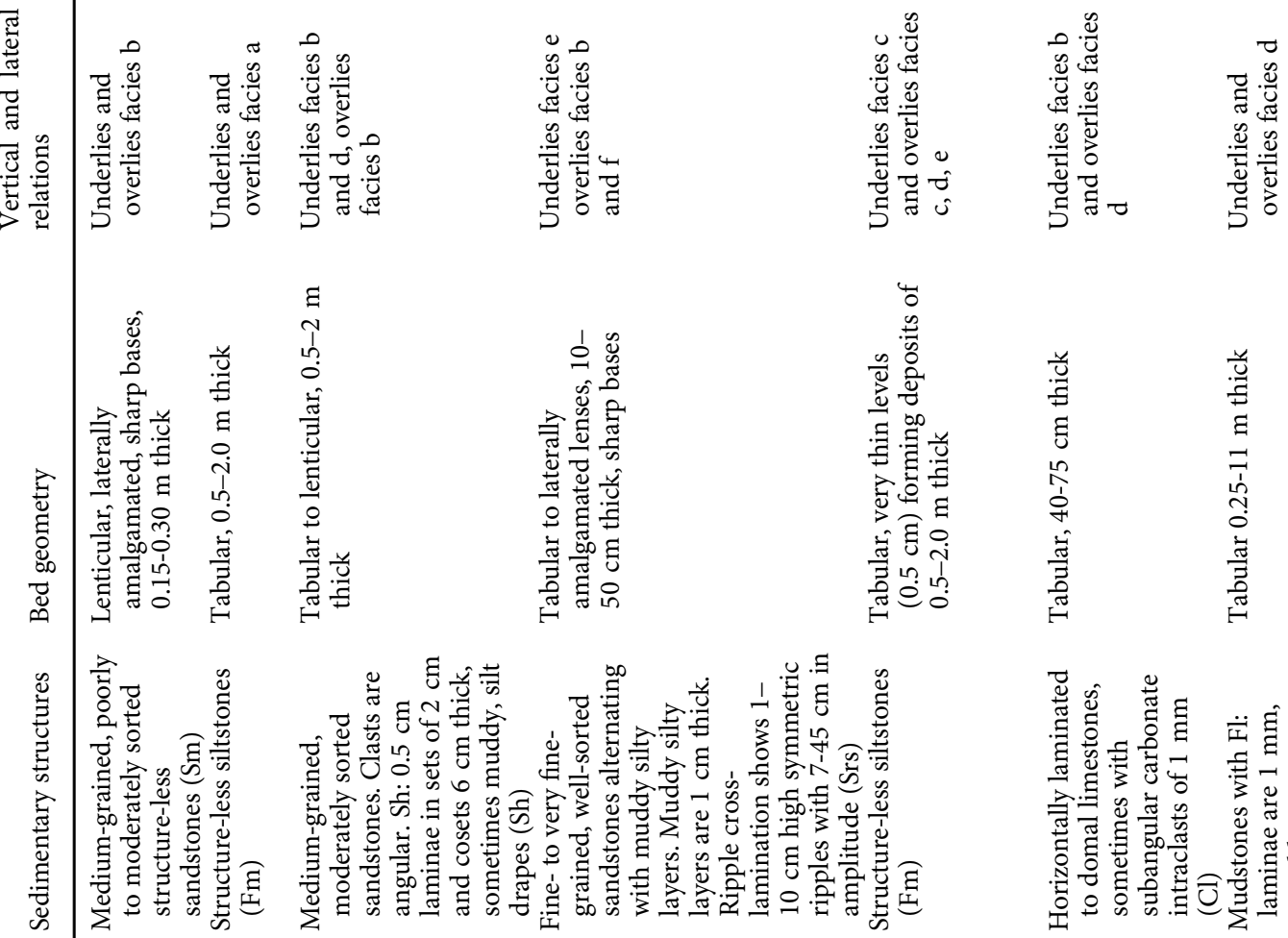

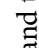

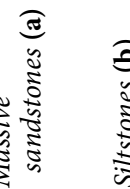

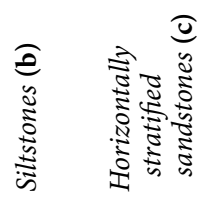

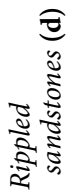

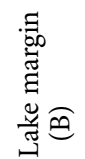

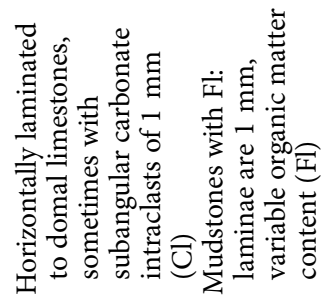




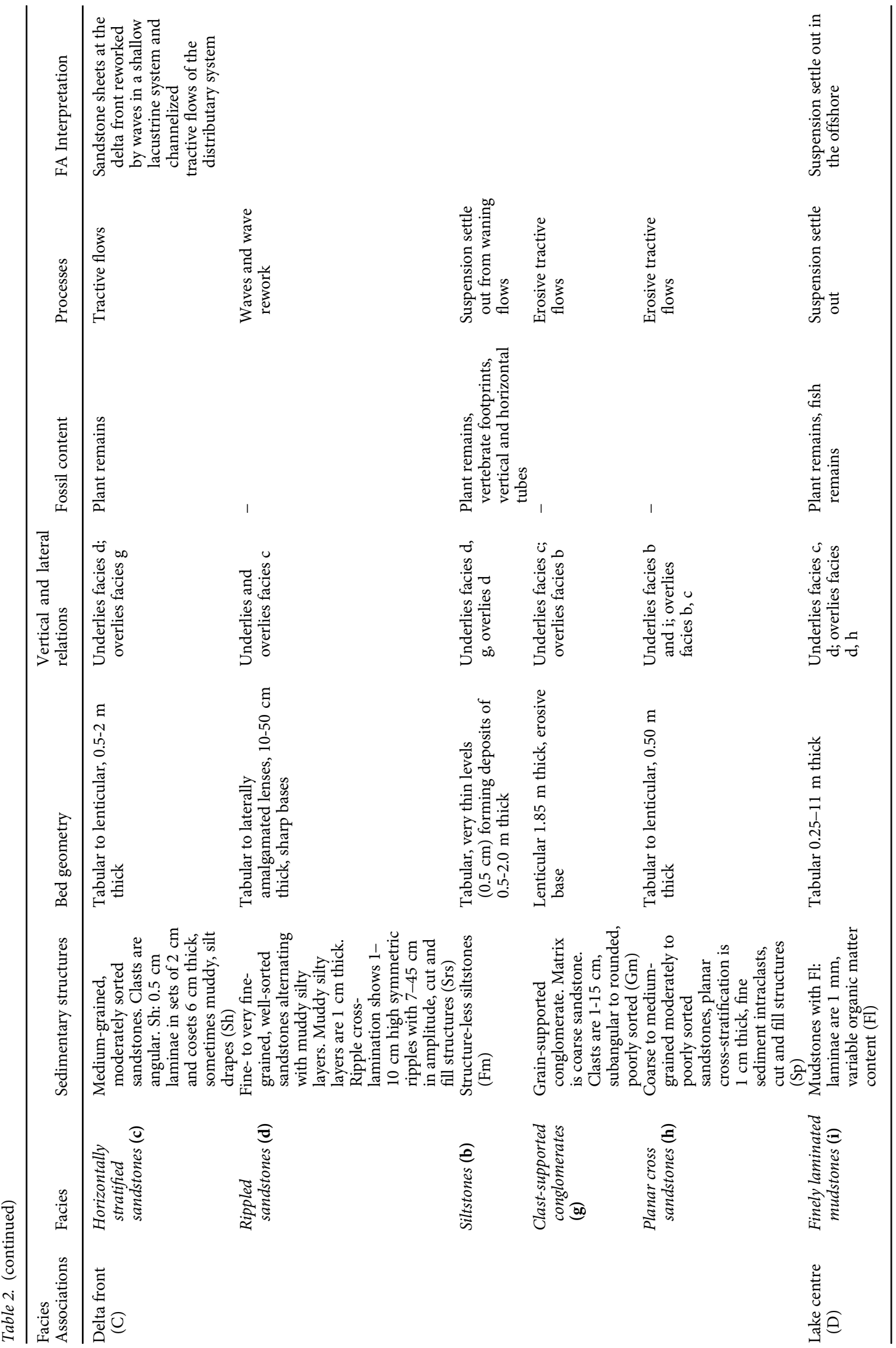


sandstone with symmetric ripple cross-lamination (Srs), with cut and fill structures of greenish grey colour (5G 6/1) (Fig. 3E) that grade upwards to structure-less siltstone $(\mathrm{Fm})$ with plant remains, vertebrate footprints, and vertical and horizontal tubes. They are overlain by grain-supported conglomerate lenses $(\mathrm{Gm})$ of medium bluish grey colour (5B 5/1) (Fig. 3F) with a coarse sandstone matrix and subangular to rounded, poorly sorted clasts from 1 to $15 \mathrm{~cm}$ in size and dark greenish grey in colour (5GY 4/1). These conglomerates are overlain by medium-grained well-sorted sandstone with horizontal stratification (Sh) of yellowish grey colour (5Y 8/1), fine- to very fine-grained (Fig. $3 \mathrm{G}$ ), coarse to medium-grained, moderately to poorly sorted symmetric rippled sandstone (Srs) of greenish grey colour (5G $6 / 1$ ), and coarse to medium-grained, moderately to poorly sorted sandstone, with planar cross-stratification (Sp) and yellowish grey colour (5Y 7/2) to light brownish grey colour (5YR 6/1).

Facies Sh, Sp and Gm represent tractive flows. Intraclasts in $\mathrm{Sp}$ suggest erosive processes while the lenticular geometry and irregular base of $\mathrm{Gm}$ suggest confined high energy erosive flow, perharps ribbonlike channels of the distributary fluvial system (Fisher et al. 2007). The Sp facies and Sh facies represent tractive flows, probably sheet flows, associated with the distributary system in the floodplain (Fisher et al. 2007). The Srs facies represents sandstone sheets at the delta front reworked by waves in a shallow lacustrine system (Fisher et al. 2007).

Facies association D. - This association is represented by facies $\mathrm{Fl}$ (Table 2; Fig. $3 \mathrm{H}$ ). This finely laminated mudstone of dark grey colour (N3) presents plant and fish remains including complete, articulated fishes, disarticulated fish remains but associated with scales and isolated scales.

This finely laminated mudrock facies (Fl) represents sedimentation from suspension settle-out processes in the offshore of a palaeolake.

\section{Depositional setting}

The depositional setting proposed for the Santa Clara Abajo Formation is a fluvial-deltaic-lacustrine system. Facies associations indicate a floodplain terminal splay, lake margin, delta front and lake-centre subenvironments (Table 2). The studied fish remains are found in the lake-centre sub-setting. The floodplain is dominated by a combination of confined flows, such as ribbon-like channels eroding the overbank, and unconfined flows represented by mostly non-erosive sandstone sheets (Fisher et al. 2007). This combination of tractive flows delivered sediment to the lacustrine system forming deltaic deposits. Lateral to this main water + sediment supply are carbonate-rich deposits. These deposits probably developed at the margin of the lake, adjacent to the siliciclastic fluvial input (Fisher et al. 2007). Carbonates present planar to domal lamination, possibly indicating a biogenic origin. If that were the case, we infer a Ca-rich provenance and the presence of microorganisms involved in the precipitation (Benavente et al. 2015). However, such interpretations require additional microfacies analyses. Different evidence of the delta front deposits, such as mudcracks, rain-drop marks, and vertical and horizontal tubes concentrated at specific boundaries of the strata, indicates pauses in the sedimentation (Smoot \& Lowenstein 1991; Young et al. 2000) that may indicate a seasonal activation of the fluvial system. Lakecentre mudstones are finely laminated, pointing to anoxic conditions probably by thermal stratification of the water column, deeper than the range of action of waves.

The stacking pattern of the unit is progradational to aggradational (Fig. 2), suggesting a general moderate creation of accommodation that is in near balance with water + sediment supply towards the top. The system is represented by a fluctuating profundal facies association sensu Bohacs et al. (2000) that corresponds to a balanced-fill lake type.

\section{Taphomomic modes}

The preservation of fish remains collected in the Santa Clara de Abajo Formation is, in general, good since it includes articulated fish but also bone fragments and scales. They show variation in the taphonomic attributes. We define three taphonomic modes of fish preservation in the Santa Clara Abajo Formation based on taphonomic attributes (Table 3). Mode A is characterized by isolated and dispersed fish remains, dominated by scales and scarce bone remains. Mode B includes disarticulated but associated fish remains with scales and bone elements. Mode $\mathrm{C}$ is dominated by articulated specimens, such as complete or almost complete individuals. Figure 4 shows the characteristics observed in the taphonomic modes.

\section{Discussion}

Fishes that inhabit lacustrine environments are exposed to diverse taphonomic agents that influence their preservation. They are affected by predation, scavenging, turbulence, flotation decay, transport, bioturbation and microbial mats, among others 
Table 3. Taphonomic modes with states defined for the fish remains of the Santa Clara Abajo Formation (Triassic) at the Santa Clara subbasin, Central area of the Cuyana Basin, Mendoza, Argentina.

\begin{tabular}{|c|c|c|c|}
\hline $\begin{array}{l}\text { Taphonomic } \\
\text { attribute }\end{array}$ & $\begin{array}{c}\text { Mode A } \\
45.6 \%\end{array}$ & $\begin{array}{l}\text { Mode B } \\
5.6 \%\end{array}$ & $\begin{array}{l}\text { Mode C } \\
48.8 \%\end{array}$ \\
\hline Remains & Bones $8 \% \quad$ Scales $92 \%$ & Bones $89 \% \quad$ Scales $11 \%$ & Bodies \\
\hline Taxa & Pseudobeaconiid & Pseudobeaconiid & Pseudobeaconiid \\
\hline $\begin{array}{l}\text { Mode of } \\
\text { fossilization }\end{array}$ & Hard part $92 \% \quad$ Cast $8 \%$ & Hard part & Hard part \\
\hline $\begin{array}{c}\text { Degree of } \\
\text { articulation }\end{array}$ & Isolate and dispersed & Disarticulated but associated & Articulated \\
\hline \multicolumn{4}{|l|}{ Compactation } \\
\hline \multicolumn{4}{|l|}{ Abrasion } \\
\hline \multicolumn{4}{|l|}{ Roundness } \\
\hline \multicolumn{4}{|l|}{ Cracking } \\
\hline \multicolumn{4}{|l|}{ Breakge } \\
\hline \multicolumn{4}{|l|}{ Oxidation } \\
\hline \multicolumn{4}{|l|}{ Recrystalization } \\
\hline \multicolumn{4}{|l|}{ Deformation } \\
\hline Orientation & $\begin{array}{c}\text { Without preferencial } \\
\text { orientation }\end{array}$ & $\begin{array}{c}\text { Without preferencial } \\
\text { orientation }\end{array}$ & $\begin{array}{c}\text { Without preferencial } \\
\text { orientation }\end{array}$ \\
\hline Cross-cutting & $\begin{array}{l}\text { Concordant } 88 \% \\
\text { Discordant } 12 \%\end{array}$ & Concordant & Concordant \\
\hline \multicolumn{4}{|l|}{ Packing } \\
\hline \multicolumn{4}{|l|}{ Sorting } \\
\hline Density & & & \\
\hline
\end{tabular}

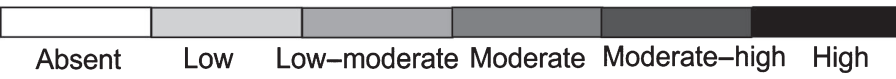

\begin{tabular}{l|c|c|c|}
\hline & & & \\
Not available Dispersed & Loosely packed & Densely packed \\
Not available Poorly sorted & Loosely sorted & Well sorted \\
Not available Low & Moderate & High
\end{tabular}

(Wilson 1988; Elder \& Smith 1988; Barton \& Wilson 2005; Imiesto et al. 2015). However, the agents are constrained by the dominant limnological conditions such as the size, deep, oxygenation, trophic stage and circulation; some of these agents are inhibited under specific limnological conditions. For example, the deep permanent stratified lakes, which have anoxic bottom, usually limited microbial growth and scavenging. The large and deep lakes display a substantial reduction in the turbulence that affects the bottom 

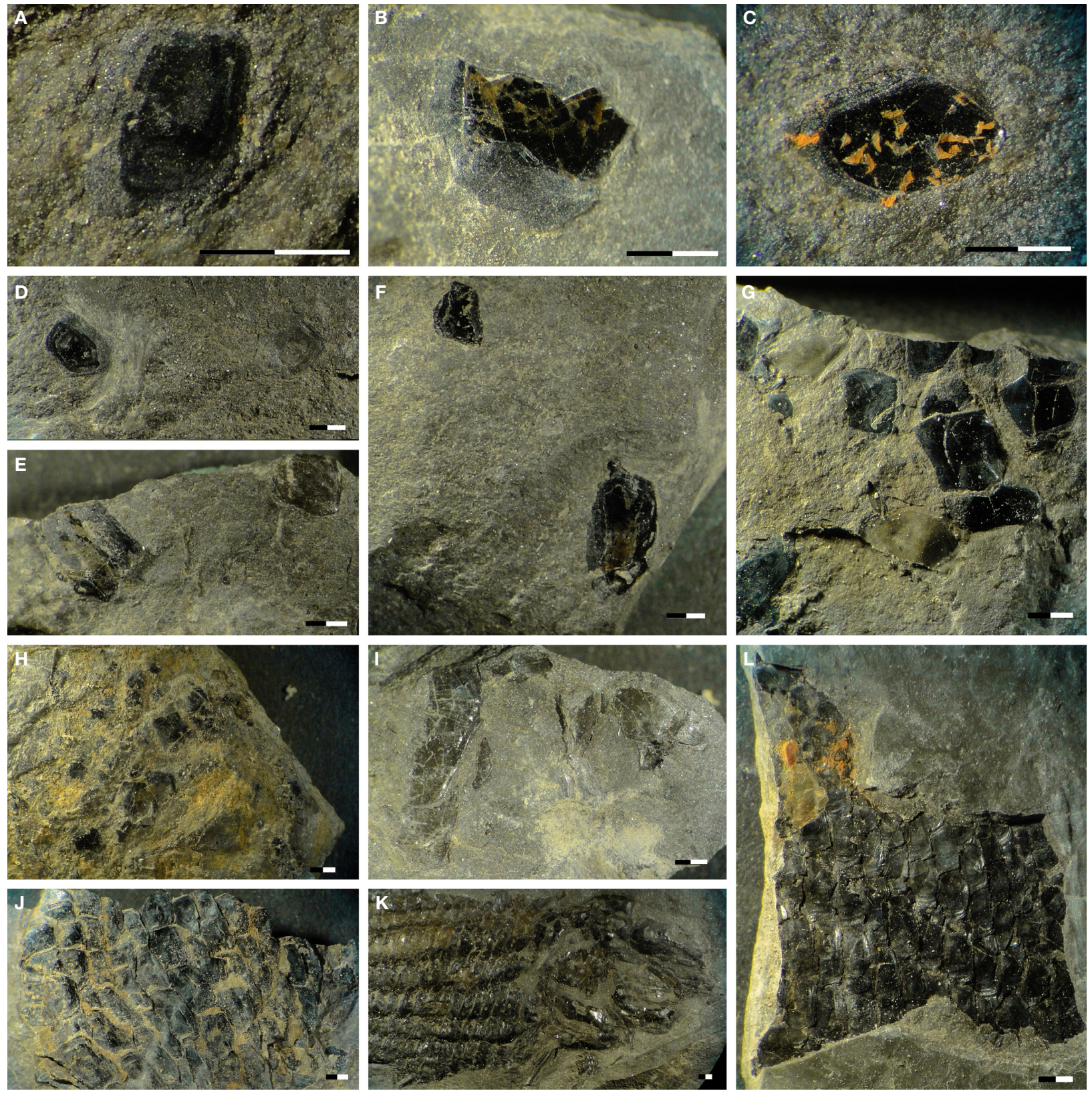

Fig. 4. Photographs of fish remains from the Santa Clara Abajo Formation, Santa Clara sub-basin, Cuyana rift Basin exemplifying the three taphonomic modes we use in this paper. A-F, taphonomic mode A: isolated and dispersed scales and fish bones. G-I, taphonomic mode B: disarticulated but associated fish remains. J-L, taphonomic mode C: articulated fish bodies, partial or complete. Scale bar $=1$ $\mathrm{mm}$. [Colour figure can be viewed at wileyonlinelibrary.com

sediments. In this contribution, we discuss the agents that potentially influence the fish taphonomy under limnological conditions suggested by the sedimentology recorded in Santa Clara de Abajo Formation.

From sedimentological information, we infer that the Santa Clara Abajo lacustrine system in which fish lived was stratified. This is supported by the microlaminated black shale lacking bioturbation and flow structures and by the absence of scavenging. The lake is interpreted as meromictic (permanently stratified) since there are no indications of oxygenated water on the lake bottom, such us underflows (Cohen 2003). Stratification is thought to be caused by a thermal condition. Oxygen concentration and temperature conditions (Barton \& Wilson 2005) in the lake water column as well as lake bottom being oxic, and disoxic or anoxic conditions are factors that will affect preservation of fish remains (Mancuso 2012). Taphonomy of fish remains is, therefore, an indicator of lake water column conditions. Such palaeolimnological conditions directly affect the pattern of disarticulation of fish carcasses. Prior to internment, the 
effects of scavenging, flotation decay or turbulence will be reflected in different taphonomic patterns. For example, scavenging at the lake bottom generates disarticulated specimens with a dispersion of elements for short distances in several directions from carcasses. Scavenging also suggests there was enough oxygen to support life at the sediment-water interface, but that could change over time (Elder \& Smith 1988; Ferber \& Wells 1995; Wilson \& Barton 1996; Barton \& Wilson 2005).

Flotation of carcasses is a consequence of bacterial decay mediated by water temperature and pressure. In lakes with low water temperature, decay gas concentrations inside the remains might not be enough to float the carcasses, and therefore, they arrive at the lake bottom and remain there undisturbed (Barton \& Wilson 2005; Mancuso 2012). In contrast, in lakes with higher water temperature, decay accelerates and gas concentrations can hold up the carcasses to or near the water surface (full flotation). Individual elements sporadically fall to the bottom as they disarticulate from the floating carcass, and the fish remains are found as disarticulated and isolated elements (beginning often with bones of the skull). However, with intermediate water temperatures, gas concentration might only be enough to lift the fish abdomen partially from the bottom (partial flotation) and fish skeletons can remain partially articulated but with dispersed abdominal elements and eventually short distance dispersion of skull and caudal fin (Elder \& Smith 1988; Ferber \& Wells 1995; Wilson \& Barton 1996; Barton \& Wilson 2005). An intact skeleton with disturbed or missing fin elements is evidence of turbulence or currents. In general, uni-directional scatter is associated with currents (Elder \& Smith 1988; Wilson \& Barton 1996; Barton \& Wilson 2005).

Recalling the preservation modes observed here, Mode A, isolated and dispersed scales, and Mode B, associated but dispersed scales probably, reflect remains that underwent flotation decay suggesting warm enough water to accelerate decay and gas concentration (full flotation). The alternative factors that could disarticulate and disperse the fish body elements were dismissed based on sedimentological context, spacial pattern and biofabric features. Mode $\mathrm{C}$, articulated fish, includes remains that did not suffer flotation decay, predation or scavenging arising from low temperatures of the water that would have prevented decay and floating of the carcasses likely because of cooler water temperatures. The consideration of exceptional preservation under microbial mat condition was rejected, in the study case, because water temperature was warm enough to favour microbial growth, the flotation decay would not be inhibited, and the carcasses show some disarticulation signs. In summary, for Santa Clara de Abajo taphonomic modes A to C correspond with warmer to cooler lake water column conditions, respectively. Of course, since this is one of the many possibilities that could lead to such fish preservational assemblage, we consider this a working hypothesis, and other factors discussed previously might have had an effect on preservation (Imiesto et al. 2015).

In a stratigraphical analysis of taphonomic modes, it is notable that there were three main situations regarding thermal conditions in the lake system: one of fluctuating thermal conditions, one of stable-warm conditions and one of stable-cold conditions (Fig. 2). The lacustrine interval 1 observed in the log (Fig. 2) shows fluctuating thermal conditions including taphonomic modes A, B and C that point to cold and warm conditions. Nevertheless, the highest abundance of fish remains, in this interval, corresponds to mode A, supporting a predominance of warm lake waters. This thermal fluctuating pattern might indicate a seasonal rainfall regime influencing the main fluvial system feeding the lake in a particular time of the year, causing a dilution effect in the lake water body that would generate a cooling of the water. The opposite situation with decreased rainfall would cause warming of a more stable lake water body. Observed data would suggest that this pattern was more extended during the lacustrine interval 1 . On a larger scale, this is directly linked to the dynamics of a balanced-fill lake system in which water + sediment supply is more or less in balance with accommodation (Bohacs et al. 2000). So, for lacustrine interval 1 , we suggest that water + sediment supply was slightly less than accommodation potential causing a hydrological restriction in the system outflow that led to warming of the lake waters. In this same interval, the conditions changed, and water + sediment supply surpassed accommodation causing dilution, cooling and outflow of the lake system. It is important to remark that we cannot know the direction (cold to warm or warm to cold) and time lapse of these changes.

Lacustrine interval 2 is dominated by taphonomic mode $\mathrm{C}$, indicative of cold water conditions with minor contribution of modes A and B. Modes A and $B$ in the lower strata of lacustrine interval 2 representing the lake in this part of the section (Fig. 2) suggest a transition from fluctuating conditions as explained for the lacustrine interval 1 but with the opposite pattern being dominated by colder conditions. Up section, in lacustrine interval 2, stable-cold conditions are interpreted. This suggests the first situation of changing lake level for this balanced-fill lake with predominantly water + sediment supply surpassing accommodation and leading to dilution, 
overflow and cooling of the water body. The less common situation corresponds to water + sediment supply lower than accommodation leading to hydrological closure and warming of the lake.

Lacustrine interval 3 (Fig. 2) represents a change from stable-cold lake water to a stable-warm pattern up section in lacustrine interval 3. This can be interpreted as an initial condition of open hydrology with water + sediment supply surpassing accommodation and generating outflow (cold lake water) changing to water + sediment supply $\leq$ accommodation with consequent hydrological closure of the system (warm lake water). In this particular case, the transition is very clear. On a regional scale, it could be possible that the climate mode changed, and seasonality was less marked during this period. Basin scale, tectonic changes that might have been controlling drainage networks feeding the system could have been more stable, causing fluctuations to be less frequent. These two controls could independently generate the observed pattern, but it is also possible that both factors were at work influencing the system.

Lacustrine interval 4 recorded in the log (Fig. 2) presents the same fluctuating conditions as the lacustrine interval 1. In this case, the pattern presents warm water conditions being dominant and changes up section to predominately cold water conditions. Lacustrine interval 4 represents a changing in the nature of fluctuations in the lake with a higher frequency in the transitions between open and close hydrology that could be closer to a seasonal influence in this case and is not dissimilar to the interpretation of the lacustrine interval 1 .

It is not possible to establish the ultimate exogenous controlling factor of the basin since it could be directly linked to a climatic control impacting water + sediment supply through rainfall, perhaps in a near to seasonal manner. Alternatively, it is also possible that in this part of the rift, local subsidence affected accommodation. Either one of these two variations would generate the observed fluctuations in the Santa Clara Abajo balanced-fill lake. The palaeoclimate effects are difficult to interpret, as the temporal resolution of our sampling does not allow differentiation of seasonal variations; therefore, it is better to just interpret the thermal and hydrological fluctuations in the lacustrine system as higher or lower in frequency of occurrence.

\section{Conclusions}

The Santa Clara Abajo Formation records a lacustrine system fed by a floodplain terminal splay with development of a delta. The thickness of bedforms and strata is moderate and conservative throughout the section, suggesting a shallow palaeolake. A shallow basin and a lake-centre facies association characterized by microlaminated black shales strongly supports thermal permanent stratification of the lake water (meromictic system). Progradational to aggradational stacking pattern and a fluctuating profundal facies association are consistent with a balanced-fill lake type for the palaeolake. Taphonomy of fish carcasses found in the black shales also supports an anoxic bottom and temperature fluctuations in the Santa Clara Abajo palaeolake through time. Three different taphonomic modes represent three thermal lacustrine system conditions: Mode A (isolated dispersed fish remains dominated by scales) corresponds to warm lake water column, Mode B (disarticulated but associated fish remains dominated by scales) corresponds to less warm lake water column, and Mode C (complete or almost complete articulated specimens) corresponds to cold lake water column. Occurrence and stratigraphical succession of these three taphonomic modes allowed interpreting a thermal lake system tendency through time including from base to top: (1) fluctuating thermal conditions (cold and warm); (2) stable-cold pattern; (3) stablewarm pattern and (4) fluctuating thermal conditions (cold and warm). Considering tectonic and palaeoclimate factors that ultimately control the filling of the basin, such thermal tendency is linked to a stratigraphical tendency of lake-level fluctuations in a balanced-fill lake from hydrological closure of the palaeolake to opening to closure again.

Aknowledgements. - We thank Simon D. Kay and Analía Forasiepi for reviewing the English of the manuscript, and Mark Wilson and an anonymous reviewer, as well as Editor Brooks Britt, for helping improving the quality of the manuscript. C.A. Benavente PICT 2014-0489 Limnogeología de secuencias carbonáticas triásicas de la Cuenca Cuyana.

\section{References}

Artabe, A.E., Spalletti, L.A., Bodnar, J. \& Morel, E.M. 2003: Estudio paleoxilológico y sedimentológico de la Formación Montaña (Triásico), provincia de Mendoza, Argentina. Ameghiniana 46, 141-152.

Barton, D.G. \& Wilson, M.V.H. 2005: Taphonomic variations in Eocene fish-bearing varves at Horsefly, British Columbia, reveal 10000 years of environmental change. Canadian Journal of Earth Sciences 42, 137-149.

Behrensmeyer, A.K. \& Hook, R.W. 1992: Paleoenvironmental contexts and taphonomic modes in the terrestrial fossil record. In Behrensmeyer, A.K., Damuth, J.D., DiMichele, W.A., Potts, R., Sues, H.D. \& Wing, S.L. (eds): The Evolutionary Paleoecology of Terrestrial Plants and Animals, 15-136. University of Chicago Press, Chicago.

Behrensmeyer, A.K. \& Kidwell, S.M. 1985: Taphonomy's contributions to paleobiology. Paleobiology 11, 105-119. 
Benavente, C.A., Mancuso, A.C., Cabaleri, N.G. \& GierlowskiKordesch, E.H. 2015: Comparison of lacustrine successions and their paleohydrologic implications in the two subbasins of the Triassic Cuyana rift, Argentina. Sedimentology 62, 17711813.

Benavente, C.A., Zavattieri, A., Mancuso, A.C., Abarzúa, F. \& Gierlowski-Kordesch, E.H. 2018: Paleolimnology of the Santa Clara Arriba paleolake (Triassic Cuyana rift basin): integrating sedimentology and palynology. Journal of Paleolimnology 59, 5-20.

Bohacs, K.M., Carroll, A.R., Neal, J.E. \& Mankiewicz, P.J.2000: Lake-basin type, source potential, and hydrocarbon character: an integrated sequence-stratigraphic-geochemical framework. InGierlowski-Kordesch, E.H. \& Kelts, K.R. (Eds): Lake Basins Through Space and Time. AAPG Studies in Geology 46, 3-34.

Bordas, A.F. 1944: Peces triásicos de la quebrada Santa Clara, provincias de San Juan y Mendoza. Physis 19, 453-460.

Chen, P.F. 2000: Using fish taphonomy to reconstruct the environment of ancient Shanwang Lake. Advances in Ecological Research 31, 483-495.

Cohen, A.S. 2003: Paleolimnology, 485. Oxford University Press, New York, The history and evolution of lake systems.

Cortés, J.M., González Bonorino, G. \& Koukharsky, M.M.L. 2003: Hoja Geológica 3369-03 Yalguaráz. Provincias de San Juan y Mendoza, República Argentina. Subsecretaría de Minería de la Nación, Servicio Geológico Minero Argentino, pp. 95.

Elder, R.L. \& Smith, G.R. 1988: Fish taphonomy and environmental inference in paleolimnology. Palaeogeography, Palaeoclimatology, Palaeoecology 62, 577-592.

Ferber, C.T. \& Wells, N.A. 1995: Paleolimnology and taphonomy of some fish deposits in 'Fossil' and 'Uinta' lakes of the Eocene Green River Formation, Utah and Wyoming. Palaeogeography, Palaeoclimatology, Palaeoecology 117, 185-210.

Fisher, J.A., Nichols, G.J. \& Waltham, D.A. 2007: Unconfined flow deposits in distal sectors of fluvial distributary systems: examples from the Miocene Luna and Huesca Systems, northern Spain. Sedimentary Geology 195, 55-73.

Fürsich, F.T., Werner, W., Schneider, S. \& Mäuser, M. 2007: Sedimentology, taphonomy, and palaeoecology of a laminated plattenkalk from the Kimmeridgian of the northern Franconian Alb (southern Germany). Palaeogeography, Palaeoclimatology, Palaeoecology 243, 92-117.

Gierlowski-Kordesch, E. \& Kelts, K. 1994: The Global Geological Record of Lake Basins, volume 1, 427 pp. Cambridge University Press, Cambridge.

Gierlowski-Kordesch, E. \& Kelts, K. 2000: Lake Basins through Space and Time. AAPG Studies in Geology 46. The American Association of Petroleum Geologists, Ohio.

Groeber, P. \& Stipanicic, P.N.1953: Triásico. In Groeber, P., Stipanicic, P.N. \& Mingramm, A.R.G. (eds): Mesozoico. Sociedad Argentina de Estudios Geográficos, Geografía de la República Argentina. GAEA 2, 13-141.

Harrington, H.J. 1971: Descripción geológica de la Hoja 22c Ramblón. Provincias de Mendoza y San Juan. Boletín n ${ }^{\circ} 114$. Dirección Nacional de Geología y Minería, Argentina, pp. 81.

Imiesto, M., Laguna, C., Florín, M., Guerrero, M.C., Chicote, A. Buscalioni, A.D. \& López-Archilla, A.I. 2015: The impact of microbial mats and their microenvironmental conditions in early decay of fish. Palaios 30, 792-801.

Larsen, D. \& Smith, G.A. 1999: Sublacustrine-fan deposition in the Oligocene Creede Formation, Colourado, USA. Journal of Sedimentary Research 69, 675-689.

López-Arbarello, A. \& Zavattieri, A.M. 2008: Systematic revision of Pseudobeaconia Bordas, 1944 and Mendocinichtys Whitley, 1953 (Actinopterygii 'Perleidiformes') from the Triassic of Argentina. Palaeontology 51, 1025-1052.

López-Arbarello, A., Rauhut, O.W. \& Cerdeño, E. 2010: The Triassic fish faunas of the Cuyana Basin, Western Argentina. Palaeontology 53, 249-276.

Makaske, B. 2001: Anastomosing rivers: a review of their classification, origin, and sedimentary products. Earth Science Review $53,149-196$.
Mancuso, A.C. 2003: Continental fish taphonomy: a case study in the Triassic of Argentina. Journal of South American Earth Sciences 16, 275-286.

Mancuso, A.C. 2009: Taphonomic analysis in lacustrine environment: two very different Triassic lake paleoflora contexts from Western Gondwana. Sedimentary Geology 222, 149-159.

Mancuso, A.C. 2012: Taphonomic analysis of fish in rift lacustrine systems: Environmental indicators and implications for fish speciation. Palaeoecology, Palaeogeography, Palaeoclimatology 339-341, 121-131.

McCune, A.R. 1987: Lakes as laboratories of evolution: endemic fishes and environmental cyclicity. Palaios 2, 446-454.

McCune, A.R. 1990: Evolutionary novelty and atavism in the Semionotus Complex: relaxed selection during colonization of an expanding lake. Evolution 44, 71-85.

Nadon, G.C. 1994: The genesis and recognition of anastomosing fluvial deposits: data from the St. Mary River Formation, southwestern Alberta, Canada. Journal of Sedimentary Research B64, 451-463.

Nichols, G.J. \& Fisher, J.A. 2007: Processes, facies and architecture of fluvial distributary system deposits. Sedimentary Geology 195, 75-90.

Noffke, N., Gerdes, G., Klenke, T. \& Krumbein, W.E. 2001: Microbially induced sedimentary structures-a new category within the classification of primary sedimentary structures. Journal of Sedimentary Research 71, 649-656.

Scholz, C.A., King, J.W., Ellis, G.S., Swart, P.K., Stager, J.C. \& Colman, S.M. 2003: Paleolimnology of Lake Tanganyika, East Africa, over the past 100 kyr. Journal of Paleolimnology 30, 139-150.

Smith, G.R. \& Elder, R.L. 1985. Environmental interpretation of burial and preservation of Clarkia fishes. In: C. J. Smiley (Ed.). Late Cenozoic History of the Pacific Northwest, 85-93. Pac. Div. Am. Assoc. Adv. Sci., Calif. Acad. Sci., San Francisco, California.

Smoot, J.P. \& Lowenstein, T.K.1991: Depositional environments of nonmarine evaporites. InMelvin, J.L. (Ed.): Evaporites, Petroleum, and Mineral Resources. Developments in Sedimentology, volume $50,189-347$.

Spalletti, L.A. 2001: Evolución de las cuencas sedimentarias. In Artabe, A.E., Morel, E.M. \& Zamuner, A.B. (eds): El Sistema Triásico en la Argentina, 81-101. Fundación Museo de La Plata 'Francisco Pascasio Moreno', La Plata.

Spalletti, L.A. \& Zavattieri, A.M. 2009: El sistema lacustre de la Formación Mollar en el depocentro triásico de Santa Clara (provincia de Mendoza, Argentina). Andean Geology 36, 236263.

Stappenbeck, R. 1910: La Precordillera de San Juan y Mendoza. Ministerio de Agricultura de la Nación. Sección Geología, Mineralogía y Minería, Buenos Aires. Anales 4, 1-187.

Stigall, A.L., Babcock, L.E., Briggs, D.E.G. \& Leslie, S.A. 2008 Taphonomy of lacustrine interbeds in the Kirkpatrick basalt (Jurassic), Antarctica. Palaios 23, 344-355.

Stipanicic, P.N. 1947: Estudio geológico, estratigráfico y tectónico de la Precordillera, al este del río de Los Patos en Sorocayense (San Juan), 270. Unpublished Doctoral thesis, Universidad de Buenos Aires, Buenos Aires.

Stoner, S. \& Holbrook, J. 2010: Geometric trends for floodplain lakes in high-accommodation floodplains and architecture of floodplain lake partitioning crevasse channels and splay deltas: AAPG Student Expo Article 90113. Texas, USA.

Talbot, M.R. \& Allen, P.A. 1996: In: Reading, H.G. (ed): Sedimentary Environments: Processes, Facies and Stratigraphy, 83-124. Blackwell Science.

Whiteside, J.H., Olsen, P.E., Eglinton, T.I., Cornet, B., McDonald, N.G. \& Huber, P. 2011: Pangean great lake paleoecology on the cusp of the end-Triassic extinction. Palaeogeography, Palaeoclimatology, Palaeoecology 301, 1-17.

Wilson, M. 1988: Reconstruction of ancient lake environments using both authochthonous and allochthonous fossils. Palaeoecology, Palaeogeography, Palaeoclimatology 62, 609-623. 
Wilson, M.V.H. 1996: Taphonomy of a mass-death layer of fishes in the Paleocene Paskapoo Formation at Joffre Bridge, Alberta, Canada. Canadian Journal of Earth. Sciences 33, 1487-1498.

Wilson, M.V.H. \& Barton, D.G. 1996: Seven centuries of taphonomic variation in Eocene freshwater fishes preserved in varves: paleoenvironments and temporal averaging. Paleobiology 22, 535-542.
Young, M.J., Gawthorpe, R.L. \& Sharp, I.R. 2000: Sedimentology and sequence stratigraphy of a transfer zone coarse-grained delta, Miocene Suez Rift, Egypt. Sedimentology 47, 1081-1104.

Zavattieri, A.M.2002: Microfloras. InStipanicic, P.N. \& Marsicano, C.A. (Eds): Léxico Estratigráfico de la Argentina, Volumen VIII: Triásico, Series B, 26, 318-323. Asociación Geológica Argentina. 